\title{
The political pivot of geography
}

\author{
GERRY KEARNS \\ Department of Geography, University of Cambridge, Cambridge CB2 3EN \\ E-mail:Gk202@cam.ac.uk \\ This paper was accepted for publication in May 2004
}

\begin{abstract}
The paper examines the geographical work of Peter Kropotkin and Halford Mackinder, making clear the political choices behind their very different geographical imaginations. Both writers responded directly to Keltie's report on geographical education and the paper uses these manifestoes as the starting point for an analysis of their relations to geographical thought and geographical institutions.
\end{abstract}

KEY WORDS: Mackinder, Kropotkin, geopolitics, imperialism, anarchism

$\mathrm{T}$ his paper explores the political nature of responses to John Scott Keltie's (1885) report on geographical education. Halford Mackinder and Peter Kropotkin both wrote prospectuses for the discipline as part of a campaign to promote geography, a campaign sponsored by the Royal Geographical Society (RGS) and focused by Keltie's report. Mackinder's 'Scope and methods' (1887) and Kropotkin's 'What geography ought to be' (1885) were prompted directly by Keltie. Both argued that geography could be made relevant to modern, post-exploration times. As ever, relevance involves political choices and utopian ambitions. Here, the two men parted company. Mackinder's 'The geographical pivot of history' (1904) showed one way geography might be relevant to current affairs. It was a resolutely imperialist vision but it was not the only alternative available to geographers pursuing relevance. This paper draws a contrast between Mackinder's imperialist vision and Kropotkin's anarchist hopes. These choices were the political pivot around which contesting geographies were organized. The RGS provided a forum for both and in this period bequeathed British geography a liberal attitude to debate that should be nurtured as both a legacy and a responsibility.

\section{The RGS and the promotion of geography}

From the 1860s, the RGS took an increasing interest in the promotion of geographical education. By the 1880 s a group of reformers within the Society had decided that a professorship in geography needed to be established at either Oxford or Cambridge to create a market for public school education in geography, to promote the training of geographical school teachers and to give geography the academic respectability the reformers thought it deserved (Wise 1986). On 17 March 1884, the Scientific Purposes Committee of the RGS proposed to council that 'an Inspector of Geographical Instruction be appointed for one year', that he should 'inform himself thoroughly on the state of Geographical Education abroad and at home' and that he should make a collection of the best available teaching aids (RGS Archives 1884). James Scott Keltie was appointed in June and he was given a written set of instructions in July. Among these were that he should determine the standpoint from which geography was taught on the continent; whether it be as adjunct to the study of physical science, or of history and politics or of commerce. He was also to discover whether geography were taught in high schools as a discipline or, as was the case in almost all English schools, as a 'mere exercise of memory' (Keltie 1885, 10).

Keltie produced his report in 1885 and his main conclusions were that, in England, geography was poorly served in the middle-class public schools. It was generally taught in the lower years and then only for about an hour and a half each week, compared with between 8 and 16 hours of classics and 4-8 hours of mathematics. In many schools, geography was the only physical science that pupils were taught. Until Oxford and Cambridge taught geography and, more importantly, examined applicants in geography, the public schools would leave the subject alone. While Britain had no university chairs in geography, there were no fewer than 12 in Germany. Perhaps the most interesting 
part of the report are the opinions it records from those who were opposed to the establishment of geography in either the universities or the public schools. The major complaint was, in the words of Keltie's summary of these objections, that geography was 'not a "manly" subject, but one fit only for elementary classes' (Keltie 1885, 31). These doubts concerned the scientific rigour, the practical relevance and the pedagogical value of the subject. The terms on which the RGS hoped to make the case were already clear in their letter to the governing bodies of Oxford and Cambridge. It insisted that geography was not 'a barren catalogue of names and facts' but 'a science that ought to be taught in a liberal way' (Keltie 1885, 80). Here they are referring to the nature of school teaching. Their sense of the applicability of geography was likewise pitched at the schoolchild for, given that the 'interests of England are as wide as the world', 'it is, therefore, a matter of imperial importance that no reasonable means should be neglected of training her youth in sound geographical know-

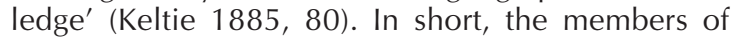
the Council of the RGS wanted Oxford and Cambridge universities to rescue geography from being badly taught in the schools of England' (Keltie 1885, 80). The problem with this case was that it failed to address the central question about the scientific standing of geography as a research discipline at the university level.

Keltie tried to address this to some degree in his report. He suggested that the synthetic nature of geography was no different to the situation in many other sciences. Meteorology, for instance, drew upon mathematics and physics for its data and to a large part its methods, but the particular integration of these two subjects around the subjects of weather and climate made meteorology a distinct discipline (Keltie 1885, 33). However, the main arguments Keltie advanced were comparative ones. In other countries, things were done differently. If Germany put geography at the heart of the teaching at its Kriegs-Akademie, why did not the staff colleges for military officers in England do the same? After all, German military efficiency was daunting and, Keltie reminded his audience, had not many people concluded, as had Chief Justice Daly in an address to the American Geographical Society, that the Franco-German War had been a war 'fought as much by maps as by weapons' (Keltie 1885, 35)? From late November 1885 until late January 1886, the RGS put on an exhibition of the globes, maps, models and textbooks that Keltie had garnered from continental Europe. At the close of the exhibition, the Society held a conference 'to consider the place of Geography in Education, and particularly the means by which can be treated as a mental exercise and raised to a level equal to its importance as an Examination subject' (RGS Archives $1886,2)$. Some prominent intellectuals from outside geography were also asked to speak on the importance of the subject as a field of research. Thus James Bryce spoke on geography and history while Henry Moseley spoke on geography and the natural sciences.

At this exhibition, Keltie, as we know, met Halford Mackinder. Since 1885, Mackinder had been teaching geography and economics for Oxford University's Extension lectures. He had an undergraduate degree in physical sciences at Oxford and he was acutely interested in the application of geography to military strategy and the problems of the British empire. Crucially, Mackinder was evangelical about the scientific role geography must play now that the fact-finding explorations were facing diminishing, or, at least, less dramatic returns. As David Stoddart (1986), Walter Freeman (1980) and Brian Blouet (1987) have argued, this new geography drew on the prestige of evolutionary science where geography was both a methodology, as with the study of the distribution of species, and a hypothesis, through the elucidation of the environmental control of biological behaviour. Here was a young man who could make this scientific case for geography and offer the universities something more than a teacher-training role in geography. In 1887, Mackinder delivered his 'Scope and methods' paper to an evening meeting of the Society and very soon he was Reader in Geography at Oxford and the most prominent academic geographer in the country. Within a few years, he was pursuing a career in politics alongside his work at Oxford and when he came back to the RGS to give his paper on the 'The geographical pivot of history' in 1904 he had already stood unsuccessfully as a parliamentary candidate, he had joined the Victoria League to signal his enthusiasm for the British empire and he was its representative on the Visual Instruction Committee of the Colonial Office, he had joined Joseph Chamberlain's Tariff Reform League, and he was Director of the London School of Economics, at the time the major centre of applied social science research in the country. Mackinder bound tightly together social Darwinism and imperialist politics in his geographical vision. In this respect, for Mackinder, his paper on 'The geographical pivot of history' delivered on the promises made earlier in his remarks 'On the scope and methods of geography'. Mackinder, at least, was clear that establishing geography in schools was vital to the future prosperity of Britain. He was also sure that demonstrating the practical application of geographical knowledge to matters of statecraft was an essential part of the case for geography. With 
his political career, his university administrative responsibilities, his teaching obligations and his promises to write textbooks, Mackinder was often over-stretched. There were many who felt, as Mackinder thought Keltie did, that he had 'too many irons in the fire' (RGS Archives 1901a). Mackinder saw all these activities as inter-related, mutually supportive and equally indispensable. He promised Keltie that:

[w] hat I want to devote the remainder of my working life to is the modernisation of our English education. It appears to me that the whole future of Britain depends ultimately on this. And for this I required a combined basis of geography, administration, politics and writing.

RGS Archives $1901 b^{1}$

We must beware not to see British geography simply through Mackinder's spectacles. As Felix Driver (2001) shows in his recent Geography militant, the nature and purpose of geography were contested, even within the RGS. At the RGS, there were not only people opposed to reform but there were also people opposed to Mackinder's brand of reform. In the first place, as a learned society, the RGS was never uniformly imperialist. In 1887, for example, the Prince of Wales asked the Council of the RGS to circulate its members on the desirability of joining a new Imperial Institute proposing to advance knowledge of and enthusiasm for the empire, in fact the very encouragement of emigration to the colonies that the Council had offered as part of the purpose of a geographical education in schools. However, the President, Lord Aberdare, refused to co-operate on the grounds that the matter had nothing to do with the central purposes of the RGS, those being 'the promotion of geographical knowledge and scientific exploration' (RGS Archives 1887, 2-3). Similarly, after the First World War, despite the opposition of many, the Council re-established links very quickly with German geographical societies and very soon had once again corresponding members there and academic visitors from there. Several other learned societies were not so quick to take this step (Cornwell 2003). This sense of being above politics extended also to the treatment of anarchist geographers such as Elisée Reclus and Peter Kropotkin.

\section{Anarchy at the RGS}

The geographical careers of Mackinder and Kropotkin show many parallels. Both disappointed many of their geographical admirers by concentrating increasingly on politics. Keltie regretted that Kropotkin's 'absorption' in politics 'seriously dimin- ished the services which otherwise he might have rendered to Geography' (Keltie 1921, 317). Both Kropotkin and Mackinder had long and valued relationships with the RGS. After his arrival in Britain in 1876, Kropotkin, in Keltie's recollection, 'soon made himself at home at our Society' (Keltie 1921, 318) ${ }^{2}$. Mackinder served on the Council during much of his career and was regularly consulted about matters such as the awarding of medals and the refereeing of papers. Both Kropotkin and Mackinder considered how Darwinian biology had taken up geographical reasoning and both wanted to see how evolutionary biology might revitalize geography. Both wrote thoughtfully about geographical pedagogy. Indeed, they must have met on many occasions at the RGS. We know only of some of these.

In April 1903, Elisée Reclus came to give one of his two lectures to the Society. The paper was on the need to use various types of spherical and relief maps in teaching. Mackinder and Kropotkin took part in the discussion. They both suggested that Reclus was being unnecessarily purist in insisting on relief models that used no exaggeration of the vertical scale and Mackinder underlined the need for public authorities to spend more on maps and models for geographical education. Mindful, perhaps of Mackinder's imperialist politics, Kropotkin referred directly to defence spending, noting that '[w] hen so much money was spent on useless things such as ironclads and the like, surely they ought to be able to find money for what was absolutely essential in carrying on the work of education' (Reclus 1903, 297). In February 1904, Kropotkin gave his paper (1904c) on 'The dessication of Eur-Asia' to the Research Department of the Society and Mackinder sent a letter as contribution to the discussion ${ }^{3}$. In this, the year of 'The geographical pivot', Kropotkin had two further very extensive articles (1904a 1904b) published in The Geographical Journal. Inside the first edition of Britain and the British seas, Mackinder (1902), presenting this as the first of a series on 'The Regions of the World', announced that forthcoming would be Reclus on 'Western Europe and the Mediterranean' and Kropotkin on 'The Russian Empire'. Neither ever appeared ${ }^{4}$. Another potential collaboration that also failed to materialize was in University Extension. Mackinder gave many lectures at these evening courses and in 1893 Kropotkin was seeking such employment proposing three possible courses: the Ice Age, the geological structure of Central Asia, and Mutual Aid (RGS Archives 1893b). Although Kropotkin gave several series of evening classes in London, it does not appear that he did so as part of any University Extension series.

Kropotkin had many friends among the geographers. Keltie and Henry Walter Bates were very 
close personal friends. Hugh Mill was certainly a warm acquaintance. Keltie commissioned works from Kropotkin for the Encyclopaedia Brittanica, for Nature and for The Geographical Journal. For most of the period between 1876 and 1917, Kropotkin was in Britain and lived mainly by such scientific writing, as well as having an income from his books. With his frugal tastes, Kropotkin recorded that after his arrival in Britain following his escape from prison in Russia, 'I soon managed very nicely, with my Nature notes and my Times paragraphs, to get a living' $(1962,261-2)^{5}$. When Kropotkin was imprisoned in France in 1882, Keltie, as secretary of the RGS, was among the many British scientists who signed a petition pleading for his release (Woodcock and Avakumović 1971). The petition failed. In 1871, another group of scientists had signed one for the release of Reclus after his detention in the aftermath of the Paris Commune (Kropotkin 1904d) ${ }^{7}$. This petition was successful. Reclus was lionized by British geographers, receiving the Gold Medal of the RGS in 1894.

At a time, then, when one section of British geography was promoting its usefulness with reference to its service to the empire, anarchists such as Reclus and Kropotkin received a warm welcome for their scientific work. Kropotkin, himself, refused a fellowship from the RGS since he could not place himself under royal patronage but still he was invited to lectures and dinners. Indeed, whereas he could not stand and toast the Queen, in obedience to etiquette, his princely status secured him the very next toast at dinner and when, as Kropotkin reported, 'everybody without exception rose', he was left 'thunderstruck' (Woodcock and Avakumovic 1971, 277). In 1904, the RGS bought a portrait of Kropotkin that is still on display (Potter 1983) ${ }^{8}$.

Mackinder, of course, was the first modern Reader in Geography at Oxford University. There is some suggestion that a friend of Kropotkin's, Robertson Smith, Professor of Arabic at Cambridge University, tried to interest Kropotkin in a Chair of Geography there in 1896 (Woodcock and Avakumović 1971). It is unlikely that this ever got beyond conversation or that Kropotkin would have accepted a position in which his political activities might have been cramped. Still, it is indicative of a very strong parallel between Mackinder and Kropotkin that their standing as physical scientists could make them plausible candidates for such appointments ${ }^{9}$. Kropotkin succeeded Huxley as the polymath abstractor of 'Recent Science' for the elite literary journal Nineteenth Century (Metcalf 1982, 282) 10 $^{10}$. The distinguished naturalist, and assistant secretary at the RGS from 1864 to 1892, Henry Walter Bates, urged Kropotkin to challenge Huxley's 'social
Darwinist' reading of evolution, giving rise to a series of articles for Nineteenth Century, which later became a book (1955a) on Mutual aid.

Mackinder's 'Scope and methods' was a direct response to Keltie's report on Geographical education. Imprisoned in Clairvaux prison, France, Kropotkin, too, received a copy of the report. In prison, he continued to write reports on science for Keltie, pleading with him to send any 'Russian, Swedish or Danish periodicals you have' so that Kropotkin might work on notes for Nature (RGS Archives 1883). At this time, Kropotkin was also writing on Russian prisons for James Knowles' journal Nineteenth Century, and it was there that he published his contribution (1885) to the campaign to establish geography in Britain. This was a very influential journal with a circulation of 20000 (Berry 2000). Indeed, one contributor claimed that to write in this journal was 'to command the attention of the world' (Berry 2000, 123). Kropotkin's piece on 'What geography ought to be' may have reached a wider audience than Mackinder's 'Scope and methods'. Kropotkin continued to take an interest in geographical education, giving, for example, the opening address to a teachers' conference in Oxford in 1893 where he restated his view of geography as a 'philosophical review of knowledge acquired by different branches of science' (1893, 359).

\section{The politics of nature}

'The geographical pivot' made a case for the relevance of geography to statecraft. Elsewhere (Kearns 1993), I have tried to explain that there were viable contemporary alternatives to Mackinder's brand of imperialist politics by examining the contrasting geopolitical economy behind the work of the Liberal theorist John Hobson. Here, I want instead to use Kropotkin to indicate an alternative version of the 'philosophic synthesis' (Mackinder 1904,421 ) that many took geography to be. I think we can trace aspects of this alternative in the works of Freshfield, Keltie, Mill and Bates. A strongly imperialist view of geography not only alienated contemporary liberals and socialists but also threatened to over-politicize geography. By this, I do not mean that geography should not take up political topics but instead that scholars should recognize that these political emphases must remain empirically open. Wrenching him from his context, we might recall the plea of Oliver Cromwell: 'I beseech you, in the bowels of Christ, think it possible you may be mistaken' (Columbia World of Quotations 1996). Unless there can be academic debate about politics, then, we face dogma not dialogue. If the national purpose is 
uncontestable, then, a relevant geography is a technical servant of goals established elsewhere. Mackinder was quite sanguine about this. In asking that people teach geography from an imperial point of view he conceded that this was to 'deviate from the impartial ways of science' but education had to serve the needs of 'the practical citizens of an empire which has to hold its place according to the universal law of survival through efficiency and effort' (Mackinder 1911, 83). There are dangers in this view. If political positions are not subject to intellectual inquiry and challenge, then, they become matters of faith.

Geography as a tool of empire threatened to close down debate in both these areas. Kropotkin, then, would appear as heretic rather than as a party to a debate. Given the capacity of the powerful to express their world-view as common sense, to realize hegemony, it becomes all the more important for intellectual societies to cultivate dissent. This is the positive reading of claims that geography must be above politics, it must be outside any single political consensus. Here, at the high noon of empire, the anarchist acted as a lightning rod for a set of positions on nature, environment and race that were radically different to those of Mackinder, a set of positions with which some, at least in the RGS, wished to identify and with which others wished at least to engage.

I will have to leave those broader claims as little more than assertions, but I will return to them in my conclusion. For now, I want to sketch some of the bases of Kropotkin's critique of Mackinder. 'The geographical pivot' offers a particular reading of nature, environment and race. Mackinder saw the world as a stage for competition, between races, between nations. This is what he meant by a 'closed political system' $(1904,422)$. The global living space was now colonized by the powerful nations and ever after '[e]very explosion of social forces, instead of being dissipated in a surrounding circuit of unknown space and barbaric chaos, will be sharply re-echoed from the far side of the globe, and weak elements in the political and economic organism will be shattered in consequence' (1904, 422). This is an explicitly biological view of societies: compete or die. It is clearly social Darwinist in a manner that recalls no-one so clearly as it does Huxley. Huxley saw nature as a cruel, relentless struggle: '[f]rom the point of view of the moralist the animal world is on about the same level as a gladiator's show' (Huxley 1955, 330). When society takes a different route it is 'setting limits to the struggle' $(1955,331)$. But the organic realities re-assert themselves in a Malthusian check upon population growth. If Britain was to hold our own in the war of industry,' it would have to introduce scientific training to produce innovative industrialists $(1955,341)$. There is a similar combination of domestic reform and international competition in Mackinder's world-view. In the closed world system, reform at home served competition abroad and '[p]robably some half-consciousness of this fact is at last diverting much of the attention of statesmen in all parts of the world from territorial expansion to the struggle for relative efficiency' (Mackinder 1904, 422). A nation acts against nature internally to better compete with other nations externally.

Kropotkin loathed Huxley's 'atrocious article'. Yet, he found all around him 'the interpretation of "struggle for life" in the sense of a war-cry of "Woe to the Weak," raised to the height of a commandment of nature revealed by science, was so deeply rooted in this country that it had become almost a matter of religion' $(1962,299)$. Kropotkin decided to challenge these lessons from nature. Nature showed at least as much co-operation as competition. Bates, whom Kropotkin knew from the RGS, was 'delighted', assuring Kropotkin: '[t]hat is true Darwinism. It is a shame to think of what they have made of Darwin' $(1962,300)$. Kropotkin drew his work (1910) to the attention of Mill, then librarian at the RGS, in terms that suggest he anticipated approval:

Did you come across my last (Lamarckian) article in the June 'Nineteenth Century'. It may interest you the editor seems to be very pleased with it - as it tends to show the relatively secondary part of natural selection in Evolution. Or, to speak more correctly not so much its 'secondary' part, as its part of selecting whole groups - not individuals - the most capable ones of adaptation.

RGS Archives $1910^{11}$

Kropotkin's argument was simple. Competition in nature could take three forms: among individuals of the same species, between one species and another, and between individuals and their environment (1995a). Among the higher animals, social instincts have developed that attenuate the first of these sets of struggles in order to make the second and, particularly, the third more efficient. Humans, among the more sociable mammals, can be no exception: ' $[\mathrm{t}$ ] o a mind accustomed to the idea of unity in nature, such a proposition appears utterly indefensible' (1955b, 77). Co-operation in society had, argued Kropotkin, reached a peak in the medieval city commune until these were subjugated by large centralized European states. In these new tyrannies social bonds were arrogated to the state in the form of citizenship, and grass-roots solidarity was treated as insubordination. 
David Harvey (1996) has subtly and persuasively argued that arguments about the natural basis of social arrangements are usually forms of special pleading used to demonize alternative, supposedly unnatural, configurations. In other words, people claim to find in nature precisely the social forms they want to legitimate in society. Kropotkin's argument was two-fold. First, that analogies with nature helped people understand social phenomena that were too complex to have yet been reduced to simple abstractions by social scientists (Kropotkin 1970). Secondly, there was a naturalistic basis to ethics in the development of a social instinct among the higher mammals (Kropotkin 1947). Demonstrating the reality of mutual aid among animals undermined the naturalistic arguments for capitalism, war and imperialism. If nature contained both co-operation and competition, the one could not be asserted over the other simply on the grounds of natural imprimatur. Further, if co-operation not only served an evolutionary purpose in the development of higher, social animals, but had also flourished as the basis of human societies at periods of greatest individual freedom, then, any civilized society might find it a virtue and a practice worth cultivating.

\section{Environment, race and civilization}

Neil Smith (2003) has suggested that one of the main intellectual debts that Isaiah Bowman owed to Halford Mackinder was the insight that geography was mutable, that the absolute space of early colonialism was now replaced by the relative space (efficiency) of the new imperialism. Blouet $(1987,165)$ also insists that Mackinder only studied the environmental constraints on imperial strategy the better to know how to rise above such 'fatalism'. Mark Bassin (1987) has identified a tension between racial and environmental determinism in German political geography of the first half of the twentieth century. Much the same is true of Mackinder. I have explained elsewhere (Kearns 1985) how I believe these concepts inter-relate in Mackinder's work. The environment was responsible for breaking up the human species into distinct local geni, or races. The nature of the environment locally produced an adaptation that was transmitted in the blood and carried culture from generation to generation. As populations grew, races moved out of their core areas and came into competition with each other. In this war of each against all, three factors were important: racial character, social fitness (education and health), and imperial strategy (alliances and exclusions). Thus the English, of the home counties at least, were relatively isolated, 'impeding intermarriage', and allowing the people of this region to share 'the English blood, one fluid, the same down the centuries, on loan for the moment in the forty million bodies of the present generation' (Mackinder 1931a, 326). This purity needed to be defended if national character were not to be endangered. The English blood, he argued, 'is valuable as carrying a certain character' $(1925,726)$. This character allowed the English to offer the gift of benign government to the world, much of which was occupied by people rendered incapable by their environment of developing or even willingly accepting such government. Education and public health could bring the English to a peak of efficiency but this efficiency had to be protected against the dumping of foreign goods in domestic markets and against the miscegenation of racial stock by immigration. Reform, eugenics and colonialism went together. Again, Mackinder was explicit, looking for the 'reconciliation of Colonial Liberalism with protection, the exclusion of coloured races and imperialism' (Mackinder 1905, 140). This liberalism was very attenuated indeed.

Finally, from a global perspective there was human expansion, diffusion and competition, a set of biological processes showing 'human history as part of the life of the world organism' $(1904,422)$. 'The geographical pivot' sketched a conflict between nomadic and sedentary peoples with the former preying upon the latter. In the pre-1492 period, the nomads of the steppe-lands leeched off the trade between the civilizations of India and Europe. The peoples of the steppe were naturally slavish, easily united under despotism. With the expulsion of the Muslim societies from Spain, the western end of the Mediterranean was opened for Christendom. The focus of Europe shifted. It now had an alternative to the overland route. It now had 'ocean-ways' (Mackinder 1900, 138). This was the period of European expansion overseas, the Columbian period, a period when nomadic predations were of least significance. However, the new closed-space era, with the globe virtually allocated between the powerful nations, would see a return to the geopolitics of land rather than sea power. Now, however, the steppe-lands had been converted from a sparse archipelago of tribes into a centralized Russian empire of railroads and industry, a new despotism. After 1917, the Bolshevik revolution only worried Mackinder the more. Land powers had to be prevented from developing sea power: Russia must not get access to a warm water port; continental Europe must be prevented from uniting behind German leadership. Now, the environment provided the stage-set directing the action of the imperial players. Land, sea, minerals and proximity were the dimensions of strategic opportunity and the elements of geopolitical calculation. 
Race and environment are inseparable in this world-view. Environment operated through shaping race. Smith and Blouet stress Mackinder's insistence on strategy, on rising above the fatalism of race and environment. Insofar as there was anything of import that was not ultimately environmental, it certainly lay outside geography. Mackinder recognized global, or general geography, which was a descriptive catalogue 'and does not concern itself so much with the interactions between its topics' (RGS Archives 1902). In contrast, regional geography dealt with precisely these interactions, in short the determination of political by physical geography: '[w]e hold that all Geography is fundamentally Physical' (RGS Archives 1902). I am not sure how much scope Mackinder allowed to ideals in countering realities. Race, as a distillation of history, impels people forward and geographical opportunities guide that force: '[s]tatesmen and diplomatists succeed or fail pretty much as they recognise the irresistible power of these forces' (Mackinder 1890, 84). Mackinder saw the question of free will as a balance between initiative and environment yet since even initiative resulted from the environmental determination of racial character, the reckoning was always in favour of the environment: '[t]emporary effects contrary to nature may be within human possibilities, but in the long run nature reasserts her supremacy' (Mackinder 1895, 375).

Kropotkin's view of the environment was quite different. He certainly shared elements of Mackinder's neo-Lamarckian perspective (Livingstone 1992). In other words, both thought the environment had a direct effect upon living phenomena, an effect passed down to following generations. For Mackinder, this was part of his racist view of society. For Kropotkin this was part of his general anti-Malthusianism. Kropotkin's argument was that biologists who were committed to Huxley's vision of intra-species individualistic competition had to view the environment as an external agent eliminating weak individuals. If organisms could not adjust to their environment, then, Kropotkin seemed to believe, there would be no progressive direction to evolution since the same range of variation would be created randomly in each generation and the same sorts of individuals eliminated (Kropotkin 1995a). However, more significant for geography were the holism and historicity of his view of the environment. In fact, Kropotkin (1912) suggested that the two main findings of nineteenth century natural science were precisely these, that there is a unity to matter and energy such that mechanical laws can explain all scales within the universe, and, secondly, that everything from stars to species show a life cycle and an evolution.
Kropotkin was quite mystical in his love of the contemplation of the unity of nature. This was not a matter of physical cause and organic response, but a series of interdependencies and structural homologies across all material scales from the atom to the cosmos. He attributed this belief to Humboldt and he claimed to find it best expressed in Goethe. His hope for geography was that it might provide 'a general view of nature as a whole' (Kropotkin 1962, 69). This is equivalent to Mackinder's general geography. Mackinder saw this as an introductory and inchoate form of knowledge, yielding its place to the causal explanations offered in regional, or political, geography. For Kropotkin, there was nothing higher than this holistic view. He praised Hugh Robert Mill's The realm of nature (1892) for offering such a synthesis and promised to send Mill his own paper on physiography (1893) with 'hope that you will approve most of the ideas of it - because they are your's as well' (RGS Archives 1893a).

The historicity of Kropotkin's view of the environment is in marked contrast to Mackinder. For Kropotkin, the environment had a history. Environmental change was a significant stimulus to human adaptation. For example, for Kropotkin (1904c) the end of the last Ice Age saw a mass of ice over Eurasia gradually melt and then drain away. During this melting period, the Eurasian landmass had been covered in lakes. As the climate warmed, these lakes dried up, leaving as desert what had once been lush valleys and as ghost towns what had once been thriving agrarian cities. As these farming areas shrank, the peoples who had been settled there were driven out and either raided or settled among the peoples on the rim of the heartland of Eurasia. To the discussion of this paper at the RGS, Mackinder contributed a letter in which he questioned the claim that invasions of Europe were triggered by climatic change. Instead, he argued that the people in question had always been nomads and were led out into Europe by rulers who saw the 'rich booty' there to be had (Kropotkin 1904c, 735). For Mackinder, then, we have a relatively stable environment and an equivalent consistency of racial character. It is in this sense, that he could argue that 'Geography should, as I see it, be a physiological and anatomical study rather than a study in development' (1931b, 268). Kropotkin disagreed. I think that Mackinder's notion of dynamic explanation (physical cause and social response) leads to the neglect of social structure in analysis. In this, Bowman followed Mackinder closely, arguing that the only scientific geography would be one with a physical basis. In that sense, social science could never be a fundamental part of geography (Smith 
2003). Kropotkin was very different. He wanted to study the social structure and social dynamics to document the importance of mutual aid, the importance of co-operation of people in the face of environmental challenge. Not surprisingly, Kropotkin's geography had a strong basis in social history. His account of the French Revolution (1986) was a classic history from below, showing how the common people combined to pressure the bourgeoisie to abolish feudalism. His account of the role of mutual aid in society (1955a) sketched the social organization of civilizations at various periods from the primitive, through the medieval, to the capitalist.

Given this concern with social structure, it is evident why Kropotkin could never share Mackinder's racism. However, this emphasis on social structure also gave Kropotkin a rather different view of the evolution of culture and civilization. For Mackinder - and 'The geographical pivot' is quite explicit on this - there is an irreversible tendency towards larger and larger political units in the world system. Bigger is later. The post-Columbian period to which he directs his warnings is characterized by the clash of empires. The English need to place themselves at the head, or at least the heart, of an Anglo-Saxon alliance that could defend the precious legacy of the English blood against Slav or Teuton.

Kropotkin (1912) saw things quite differently. For him, there was a permanent tension between mutualism and authoritarianism. Authoritarianism congealed around monopolies of property or knowledge that sustained priests or generals. These groups constituted states to defend their privileges. But this was always being challenged from below. The nineteenth century had undertaken the business of liberating people from feudal economic servility and from absolutist political servility. It had done so under pressure from below. Yet this tension between authoritarianism and mutualism was always being recreated. The economic revolutions of the nineteenth century remained incomplete because they left untouched the monopoly power of property. Even within socialism, the same tension could be seen between statist (marxist) and communitarian (anarchist) tendencies.

Kropotkin and Mackinder thus had very different attitudes towards scale in political systems. For Mackinder, localism was chiefly valuable as a way of undermining class identification, a loyalty threatening to undermine the authority of the state (Kearns 1985). For Kropotkin, the mission of local associations was to replace the central state altogether. When Mackinder looked at London, he saw the distant environmental causes that had selected the site for settlement but more significantly he saw inertia: 'a "stratum" of human beings comparable with a stratum of coal or of soil; a "deposit" of human energy, skill, and a habit of working together' (Mackinder 1921, 383). It is a pity that Mackinder did not look more deeply into those habits. When Kropotkin looked at London that is just what he did. Kropotkin argued that the civilization of each town had:

[S]lowly grown and ripened through the co-operation of generations of its inhabitants before it could become what it is today. And even today, the value of each dwelling, factory and warehouse, which has been created by the accumulated labour of the millions of workers, now dead and buried, is only maintained by the very presence and labour of legions of the men who now inhabit that special corner of the globe. Each of the atoms composing what we call the Wealth of Nations owes its value to the fact that it is a part of the great whole. What would a London dockyard or a great Paris warehouse be if they were not situated in these great centres of international commerce?

Kropotkin 1995b, 14

Mutualism made a mockery of claims to private property, in land or ideas.

\section{Conclusion}

In their ideas of nature, race, environment and culture, Kropotkin and Mackinder differed greatly. 'The geographical pivot' may mark the highest water of the tide of imperialism within geography. Mackinder was constructing a subject that would train imperial minds. Geography was relevant. He offered geography as a philosophic synthesis of other sciences, drawn around the hypothesis of environmentalism. This kept physical and human geography together as cause and effect. Geography was scientific. Kropotkin's geography was equally relevant. He wanted to counter 'national selfconceit' $(1885,942)$. Prejudice was based on ignorance. Instead, children should learn that 'all nationalities are valuable to one another' and that 'political frontiers are relics of a barbarous past' (1885, 942). Enlightenment would also disperse racism. Geography could take up the lessons of ethnology and show that the so-called primitive peoples were not so different to ourselves and thus geography might engender greater respect for people too frequently seen as 'a mere nuisance on the globe' $(1885,943)$. Kropotkin's geography was scientific. It contemplated the unity of the cosmos and by showing how dependent people were upon complex webs of plants and animals could 'awaken in our children the taste for natural science' (1885, 943). The historicity of the environment gave 
geographers a non-reductionist way of looking at the inter-relations between human, other animal, plant and mineral systems. His emphasis on community and locality put social science concepts at the heart of human geography.

And Kropotkin did all this at the high noon of imperialism and very largely inside the institution supposedly dedicated to little else. We should celebrate those geographers who welcomed Kropotkin as a refugee, respected him as a scientist, and cherished him as an independent thinker. Kropotkin had his disciples and they formed a network that sustained a liberal geography. At the RGS we must include Bates, Keltie and Mill. Outside London we should acknowledge Patrick Geddes, A.J. Herbertson and Herbert Fleure (see Kearns 2004) among others. Traditions of academic and political tolerance are valuable and fragile and the critique of colonialism is yet unfinished business at the RGS.

\section{Acknowledgements}

I would like to thank Sarah Strong for helping me find my way around the RGS Archives at a time when the Department was in the midst of relocation. I would also like to thank the following for discussions: Millie Glennon, Mike Heffernan, Phil Howell, Steve Legg, Simon Reid-Henry, Andy Tucker, Hannah Weston.

\section{Notes}

1 Under serious strain at the time, Mackinder misdated the letter 1891.

2 Kropotkin's many letters to the officers of the RGS show him borrowing books and wall charts, getting advice about drawing maps, refereeing papers, translating papers, and writing notes on Russian geographical works.

3 I will comment below on their differences on this occasion.

4 Of the 12 projected volumes only Mackinder on Britain, David Hogarth on 'The Nearer East', and Joseph Partsch on 'Central Europe' never appeared. Keltie on 'Africa' was another unfinished and unpublished work in the series.

5 The scientific notes were, in the main, summaries of articles that had appeared in the Russian scientific periodicals. For The Times Kropotkin reported on Russia by reading Russian language newspapers.

6 William Morris, Patrick Geddes and Alfred Wallace were among the signatories.

7 Wallace was common to both lists.

8 The painting was by Miss Nellie Heath, who, as a young girl would play with Kropotkin's daughter at his house.

9 Perhaps even more requisite at Cambridge where geography was subject to closer, critical attention from earth scientists than at Oxford where the relations with history were more determinant.
10 Huxley had overseen these articles from 1877 to 1880 and the series was revived for Kropotkin in 1895.

11 In fact the article appeared in the issue for July.

\section{References}

Bassin M 1987 Race contra space: the conflict between German Geopolitik and National Socialism Political Geography Quarterly 6 115-34

Berry N 2000 Articles of faith: the story of British intellectual journalism Waywiser Press, London

Blouet B W 1987 Halford Mackinder: a biography Texas A\&M University Press, College Station TX

Columbia World of Quotations 1996 No. 15415 Columbia University Press, New York (http://www.bartleby.com/66/) Accessed 2 December 2003

Cornwell J 2003 Hitler's scientists: science, war and the devil's pact Viking, New York

Driver F 2001 Geography militant: cultures of exploration and empire Blackwell, Oxford

Freeman T W 1980 A history of modern British geography Longmans, London

Harvey D 1996 Justice, nature and the geography of difference Blackwell, Oxford

Huxley T H 1955 [1888] The struggle for existence in human society in Kropotkin P Mutual aid Extending Horizons Books, Boston MA 329-41

Kearns G 1985 Halford Mackinder in Freeman T W ed Geographers: Biobibliographical Studies 9 71-86

Kearns G 1993 Fin-de-siècle geopolitics: Mackinder, Hobson and theories of global closure in Taylor $\mathbf{P}$ ed Political geography of the twentieth century Belhaven Press, London 9-30

Kearns G 2004 Environmental history in Duncan J S, Johnson N C and Schein $\mathbf{R}$ eds A companion to cultural geography Blackwell, Oxford 194-208

Keltie J S 1885 Geographical education: report to the Council of the Royal Geographical Society John Murray, London

Keltie J S 1921 Obituary. Prince Kropotkin The Geographical Journal 57 316-9

Kropotkin P 1885 What geography ought to be Nineteenth Century 18 940-56

Kropotkin P 1893 On the teaching of physiography The Geographical Journal 2 350-9

Kropotkin P 1904a The orography of Asia, I The Geographical Journal 23 176-207

Kropotkin P 1904b The orography of Asia, II The Geographical Journal 23 331-61

Kropotkin P 1904c The dessication of Eur-Asia (with discussion) The Geographical Journal 23 722-41

Kropotkin P 1904d Obituary. Elisée Reclus The Geographical Journal 24 337-43

Kropotkin P 1910 The direct action of environment on plants Nineteenth Century and After 68 58-77

Kropotkin P 1912 [1904] Modern science and anarchism Freedom Press, London

Kropotkin P 1947 [1922] Ethics: origin and development Tudor, New York 
Kropotkin P 1955a [1902] Mutual aid: a factor of evolution Extending Horizons Books, Boston MA

Kropotkin P 1955b [1891] Mutual aid among savages in Kropotkin P Mutual aid: a factor of evolution Extending Horizons Books, Boston MA 76-114

Kropotkin P 1962 [1899] Memoirs of a revolutionist The Cresset Library, London

Kropotkin P 1970 [1898] Anarchism: its philosophy and ideal in Baldwin $\mathbf{R} \mathbf{N}$ ed Kropotkin's revolutionary pamphlets Dover, New York 114-44

Kropotkin P 1986 [1909] The Great French Revolution, 1789 1793 vols I and II Elephant Editions, London

Kropotkin P 1995a [1910] The theory of evolution and mutual aid in Kropotkin P Evolution and environment Black Rose Books, Montreal

Kropotkin P 1995b [1892] The conquest of bread and other writings Cambridge University Press, Cambridge

Livingstone D N 1992 The geographical tradition: episodes in the history of a contested enterprise Blackwell, Oxford

Mackinder H J 1887 On the scope and methods of geography Proceedings of the Royal Geographical Society 9 14160

Mackinder H J 1890 The physical basis of political geography Scottish Geographical Magazine 6 78-84

Mackinder H J 1895 Modern geography, German and English The Geographical Journal 6 367-79

Mackinder H J 1900 The great trade routes Journal of the Institute of Bankers 21 1-6, 137-55 266-73

Mackinder H J 1902 Britain and the British seas Heinemann, London

Mackinder H J 1904 The geographical pivot of history The Geographical Journal 23 421-37

Mackinder H J 1905 Man-power as a measure of national and imperial strength National and English Review 14 136-45

Mackinder H J 1911 The teaching of geography from an imperial point of view, and the use which should be made of visual instruction Geographical Teaching 6 79-86

Mackinder H J 1921 Geography as a pivotal subject in education The Geographical Journal 57 376-84

Mackinder H J 1925 The English tradition and the Empire: some thoughts on Lord Milner's credo and the Imperial Committees United Empire 16 724-35
Mackinder H J 1931a The human habitat Scottish Geographical Magazine 47 321-35

Mackinder H J 1931b Comments in discussion of S. W. Wooldridge and D. J. Smetham, 'The glacial drifts of Essex and Hertfordshire, and their bearing upon the agricultural and historical geography of the region' The Geographical Journal 73 266-9

Metcalf P 1982 James Knowles: Victorian editor and architect Clarendon Press, Oxford

Mill H R 1892 The realm of nature: and outline of physiography J. Murray, London

Potter S R 1983 Peter Alexeivich Kropotkin, 1842-1921 in Freeman T W ed Geographers: Biobibliographical Studies 8 63-9

Reclus E 1903 On spherical maps and reliefs (with discussion) The Geographical Journal 22 290-9

RGS Archives 1883 Kropotkin correspondence Kropotkin to Keltie 22 January

RGS Archives 1884 Council Minutes 24 March

RGS Archives 1886 Council Minutes 18 January

RGS Archives 1887 Council Minutes 14 March

RGS Archives 1893a Mill correspondence, 3 LBR MSS. Kropotkin to $\mathrm{H}$ R Mill 23 March

RGS Archives 1893b Mill correspondence, 3 LBR MSS. Kropotkin to H R Mill 14 November

RGS Archives 1901a Mackinder correspondence 1887-1910. Mackinder to Keltie 27 January

RGS Archives 1901b Mackinder correspondence 1887-1910. Mackinder to Keltie 2 March

RGS Archives 1902 Mackinder correspondence 1887-1910. Mackinder to Keltie 23 August

RGS Archives 1910 Mill correspondence, 3 LBR MSS. Kropotkin to H R Mill 20 July

Smith N 2003 American empire: Roosevelt's geographer and the prelude to globalization University of California Press, Berkeley

Stoddart D R 1986 On geography and its history Blackwell, Oxford

Wise M J 1986 The Scott Keltie report 1885 and the teaching of geography in Great Britain The Geographical Journal 152 367-82

Woodcock G and Avakumović I 1971 [1950] The anarchist prince: a biographical study of Peter Kropotkin Schocken Books, New York 